This is the final pre-publication version of: Murphy, Sean, Culpeper, Jonathan and Gillings, Mathew (2020) What do students find difficult when they read Shakespeare? Problems and solutions. Language and Literature 29(3): 302-326. It may contain minor errors or infelicities.

\title{
What do students find difficult when they read Shakespeare? Problems and solutions
}

Sean Murphy

Lancaster University, UK; Manchester Metropolitan University, UK; University of

Barcelona, Spain

Jonathan Culpeper

Lancaster University, $U K$

Matthew Gillings

Vienna University of Economics and Business, Austria

Michael Pace-Sigge

University of Eastern Finland, Finland

Corresponding author: Sean Murphy, Department of Linguistics and English

Language, Lancaster University, Lancaster, LA1 4YL, UK

Email: s.e.murphy@lancaster.ac.uk

\begin{abstract}
Teaching and learning Shakespeare takes place across the world. Pedagogical matters have been the subject of much discussion in the last few decades. This paper begins by reviewing that discussion, showing how different approaches - textual, contextual and active (or performance) - connects with the language of the plays. No study, it is pointed out, has conducted an empirical investigation as to what exactly students find problematic when they read the language of Shakespeare's plays, an obvious first step, one might think, in designing an approach. The main aim of this paper is to describe a study designed to do exactly this. It was conducted with two groups of Shakespeare students, one with English as a first language and one with English as an additional language. Participants were asked to identify difficulties in extracts from plays, rate specific linguistic forms according to difficulty, and discuss what they think of Shakespeare's language. Common areas of difficulty included archaic words, borrowings from other languages, coinages and false friends. With these findings in mind, the paper briefly reflects on pedagogical solutions that are corpus-related, arguing that these address some of the problems associated with traditional textual approaches by requiring the active involvement of learners, treating language in a contextualised fashion and focussing on the language itself.
\end{abstract}

Keywords corpus linguistics, corpus stylistics, language, learning, Shakespeare, stylistics, teaching

\section{Introduction}

William Shakespeare is a global phenomenon. A 2016 online study carried out by the British Council ${ }^{1}$, into the extent of Shakespeare's influence abroad, examined the views of over 18,000 people in 15 countries and territories ${ }^{2}$ and found that $78 \%$ of respondents had experienced Shakespeare's work, $44 \%$ had read Shakespeare or watched a film adaptation of his plays, and $30 \%$ had been taught Shakespeare at school or university. 
This is the final pre-publication version of: Murphy, Sean, Culpeper, Jonathan and Gillings, Mathew (2020) What do students find difficult when they read Shakespeare? Problems and solutions. Language and Literature 29(3): 302-326. It may contain minor errors or infelicities.

Moreover, a 2011 joint RSC/British Council study estimated that $50 \%$ of the world's schoolchildren and at least 64 million children a year study Shakespeare ${ }^{3}$. However, there is plenty of evidence that student encounters with Shakespeare are often far from the joyous experiences one might hope for, the main culprit being the language, as this comment from a student makes clear: 'Shakespeare uses overcomplicated sentence structure to say simple things which makes him seem pretentious and hard to understand, with old and outdated vocabulary'. ${ }^{4}$ Before we, as school or university teachers, can begin to address this problem, we need to understand it better. There is, however, a scarcity of empirical work that addresses what exactly students find difficult when they read Shakespeare's language, reading being the dominant mode of contact with Shakespeare in the classroom (and before performance, a play is usually read). There has been a little empirical work on Shakespeare's sonnets (see Zirker et al. 2018, forthcoming), but none, as far as we are aware, based on the language of the plays. Thus, we undertook such a study. The key question driving our study was: what difficulties do learners experience when reading Shakespeare? Given the global reach of Shakespeare, for many students English will be an additional language, which leads to a second, closely related, research question: are there differences between the difficulties experienced by first-language and additional-language speakers of English? $?^{5}$ The answers to these research questions go right to the heart of the experience of encountering Shakespeare's language, and clearly have relevance to educational practices across the world. It should be noted that our study is not designed to discover whether there are any distinctive difficulties in reading Shakespeare's works as opposed to those of his contemporaries (including writings of other genres). ${ }^{6}$

Pedagogy is certainly not a stranger to Shakespearean studies. This paper begins by reviewing, particularly with language in mind, the current pedagogies for teaching and learning Shakespeare. It will show that no approach is premised upon detailed research about what students find difficult, instead particular approaches seem to be driven by particular agendas and interests. The following section, Section 3, describes our reading difficulties study, covering method, results and discussion. Section 4 briefly reflects on the role for corpus-related resources and practices in teaching and learning in meeting those difficulties.

\section{Pedagogy and Shakespeare's language}

Teaching and learning Shakespeare is difficult because the plays contain the language of 400 years ago and much has changed. Not surprisingly, therefore, much has been written about how to do it. Pedagogies for teaching Shakespeare in school and university classrooms seem to fall into three groups: textual, contextual and active (or performance) (cf. Olive, 2015: 80). Textual approaches are the most traditional, stereotypically consisting of literary-critical 'close reading' in the classroom, with the teacher translating difficult words and phrases. Within this camp, we could also place the use of simplified texts. SparkNotes, for example, presents Shakespeare's plays in two columns - the original play on the left and a simplified parallel modern-day 'translation' on the right. Contextual approaches, partly driven by historicism and cultural materialism, advocate placing Shakespeare's texts in context, the context of Shakespeare himself, his family, the people he worked with, the society of the time, the political and socio-cultural events, and so on. An extension of this approach is to make connections with the contexts with which students might be familiar. For example, the increasing public focus in the UK on immigration has led to some pointing to The Book 
This is the final pre-publication version of: Murphy, Sean, Culpeper, Jonathan and Gillings, Mathew (2020) What do students find difficult when they read Shakespeare? Problems and solutions. Language and Literature 29(3): 302-326. It may contain minor errors or infelicities.

of Sir Thomas More (1601-4) (thought to be the only surviving play script to contain Shakespeare's own handwriting). The part purportedly penned by Shakespeare contains a speech by Sir Thomas More addressing the anti-immigration mob on the streets of London, a scene that echoes the events of the play's time. Paradoxically, by making such connections across contexts, there is a movement towards universalisation rather than contextualisation. The third group of approaches concerns active methods or performance. These methods stand as a kind of counterpoint to the textual methods involving reading sitting down. Rex Gibson, partly through his leadership of the Cambridge School Shakespeare project, is usually credited as the pioneer here, though there were other motivating forces including the rise of performance criticism in Shakespeare studies, where performance is seen as an act of critical interpretation. For these approaches, the text is second to drama. As Gibson puts it, 'Shakespeare was essentially a man of the theatre who intended his words to be spoken and acted out on stage. It is in that context of dramatic realisation that the plays are most appropriately understood and experienced' (2016: vi).

It is important to note that amongst these three groups of pedagogical approaches there is one clear winner. An illustration of this point appears in the first issue of Teaching Shakespeare (2012: 7), a magazine published by the British Shakespeare Association and devoted to pedagogical issues. Five teachers are reported giving their snap reactions to the question 'which teaching methods do you consider most useful for teaching Shakespeare?' as follows:

- Seeing it performed FIRST!

- When language analysis, and discussions about the language, come through use of the text in performance.

- Freeze frames, thought tracking, what-seating, interviewing characters, roleplay, learning soliloquies by heart, supplementing reading with a range of multimodal adaptations.

- Taking the time to perform.

- Emphasising that the text only exists as a blueprint for performance, and that it only stands out when we stand up to explore it! Get them acting and feeling the language in their mouths!

What is striking is the dominance of the active, performance approaches. As Schupak (2018: 163), reviewing Shakespeare and performance pedagogy, notes, 'Performance pedagogy has become an - or perhaps "the" - established practice for teaching Shakespeare'. Nevertheless, even amongst converts, there is one regularly acknowledged difficulty with performance pedagogies: the 'Achilles heel of performance pedagogy is time' (Schupak, 2018: 171); in other words, it takes a lot of time to prepare and conduct performances. This is an important practical consideration. However, we would argue against purely performance-based approaches for more fundamental reasons.

Trevor Wright, in his popular book How to be a Brilliant English Teacher, points to a problem with performance approaches:

Much excellent work has been done about active Shakespeare teaching. [...] However, such work doesn't always finally address the text itself. I have stood 
This is the final pre-publication version of: Murphy, Sean, Culpeper, Jonathan and Gillings, Mathew (2020) What do students find difficult when they read Shakespeare? Problems and solutions. Language and Literature 29(3): 302-326. It may contain minor errors or infelicities.

in the corner of many drama studios where children have been attempting lively activities whose efforts have been limited by the fact that, ultimately, there are still words and phrases there that they didn't understand. (2005:13)

Even Schupak (2018: 174) acknowledges that 'a bad actor can perform chunks of texts with nothing more than the most general comprehension of what is going on'.

Schupak's (2018: 174) recommended solution is to 'ensure that student-actors perform through the text and not around it', and this can be done, we are told, by turning to the work of Cicely Berry. Berry, a doyen of the active approaches, had created a considerable number of teaching materials (e.g. The Working Shakespeare Library, 2004), including materials that purport to focus on Shakespeare's language. These exercises, Schupak (2018: 175) suggests, help students 'feel and apprehend the weight of Shakespeare's language'. This is, of course, somewhat vague, but Schupak (2018: $175)$ provides examples of Berry's exercises,

Berry has actors walk around the room and change direction at every mark of punctuation. [...] In other exercises, she has them, for instance beat out the iambic and diameter, kick an object at the end of every line of text or perform a soliloquy as a dialogue.?

We would not deny that such exercises are highly likely to be profitable in understanding aspects of Shakespeare's punctuation and metre, but do they help with the aspects of the language that students actually find difficult? What about the 'words and phrases' that Wright alludes to, or are these not so important? Our study will find out.

In fact, there is an even more fundamental reason why pursuing a purely performance-based approach is not optimal, and it will be one with which scholars of stylistics are familiar. A performance of a specific play ultimately arises from the text of a specific play, just as a performance of Mozart's Requiem comes from the score of his Requiem, not from his Eine Kleine Nachtmusik, or from Bach's St Matthew Passion. Consequently, it behoves us to attend to the text. Short $(1981,1998)$, a pioneer of the stylistics of drama, explains his concerns with dramatic performances:

In ontological terms, each production of a play would appear to be a play PLUS an interpretation of it, in that the director and actors have to decide which elements to focus on, emphasize in performance, etc. (Short 1998: 8)

And the ramifications of this are that:

Both meanings and values will change not just from one production to another but also from one performance of a particular production to another. There then becomes no play to criticise [...] critical discussion becomes impossible unless the two critics concerned have both seen and are arguing about exactly the same performance. (Short, 1981: 181)

What this suggests for the stylistic analysis of drama is that the play-text should be the object of study, rather than performance. We, however, would not argue that the playtext should be the sole object of study. Performance is relevant and remains an 
This is the final pre-publication version of: Murphy, Sean, Culpeper, Jonathan and Gillings, Mathew (2020) What do students find difficult when they read Shakespeare? Problems and solutions. Language and Literature 29(3): 302-326. It may contain minor errors or infelicities.

important matter in the analysis of drama, as Keir Elam points out, 'the written text/performance text relationship is not one of simple priority but a complex of reciprocal constraints constituting a powerful intertextuality' (1980: 209).

Let us turn to the other pedagogical groups once again. Contextual approaches, one might think, are a non-starter if one's concern is the language, as by definition they are con-textual rather than textual. However, we should remember that linguistics is not confined to, for example, structuralist or generative endeavours. The dramatic rise of the sub-fields of sociolinguistics and pragmatics over the last four decades is testament to the importance of studying language context. It is no surprise, therefore, that papers on Shakespeare's language appear in, for example, the Journal of Historical Pragmatics (e.g. Honegger, 2006; Lanteigne, 2014; Person, 2009; Rudanko 2007), that Lynne Magnusson, an important figure in the study of Shakespeare's language, should have written the volume Shakespeare and Social Dialogue: Dramatic Language and Elizabethan Letters (1999), a volume that is anchored in sociopragmatics; or that monographs on the pragmatics of Shakespeare have appeared (e.g. Rudanko 1993; Kizelbach 2014) ${ }^{8}$ From the point of view of schoolteachers, the issue seems to be not whether some elements of a contextual approach should be used - the consensus being that they should - but 'whether they should be used at an introductory or later stage in working on the text' (Olive, 2015: 82). The parallel question in linguistics is when to teach pragmatics to learners of a foreign language. Pragmatic issues for learners might include, for example, in which specific contexts might it be appropriate to use the word please, to use a request formed with an imperative, or to refer to somebody by their first name. A reader of Shakespeare might ask similar questions (please had yet to evolve as a politeness marker, but the question could be asked of the not dissimilar I pray you I prithee). The answer in linguistics research is clear: pragmatics can be taught from the very beginning (see, for example, Félix-Brasdefer and Cohen, 2012). However, this point is qualified. The pragmatics that is taught 'should be congruent with the level of grammatical knowledge (and the level of linguistic proficiency) of the learner' (FélixBrasdefer and Cohen, 2012: 659). This assumes then that the learner is also receiving input on the more traditional areas of linguistic proficiency, such as the grammar and the lexis, in addition to input on pragmatics. In other words, a contextual approach to Shakespeare alone is not sufficient for a complete understanding of the language of a text. Moreover, we should raise the same question that we did for performance approaches: is it in fact the more contextual, the more pragmatic aspects that students are finding difficult, and, if so, what are those aspects?

Textual approaches to teaching Shakespeare have been blighted, until recently, by a lack of creativity, both with respect to available resources and the actual practices deployed in the classroom. The 'close reading' of play-texts is seen as a traditional literary-critical approach. Aside from the fact that the approach denies the performance aspect of a play, it has been criticised for promoting the traditional pedagogy of the 'construe method', which involves a teacher going through a text line-by-line, providing translations, glosses and interpretations. The main resource here is the modern edition of the play, providing notes to help 'translate' and explain any difficulty. One general problem associated with this method is that the learner is passive. The method is stultifying and demotivating. In Gorlewski and Shoemaker's (2013) study of approaches to teaching Shakespeare in schools, reading approaches scored the lowest for comprehension and were considered to be the least enjoyable - the latter probably being a causal factor in the former. A second problem with reading approaches is that learners 
This is the final pre-publication version of: Murphy, Sean, Culpeper, Jonathan and Gillings, Mathew (2020) What do students find difficult when they read Shakespeare? Problems and solutions. Language and Literature 29(3): 302-326. It may contain minor errors or infelicities.

are presented with a fixed set of meanings, of equivalences. This does not sit well with decades of work in literary-critical scholarship, which has moved away from positivist, essentialist readings, and has embraced post-structuralism, reader response, subjectivity, and so on. Of course, these criticisms mostly apply to the traditional textual approaches; not every textual approach is so passive or geared towards fixed meanings (Olive, 2015: 62 cites McDonald et al. 2012 as an example of a work that takes a more enlightened close reading approach). From the perspective of a linguist, notes in modern editions of Shakespeare's plays have an additional problem: they describe the word in the specific context in which it appears in Shakespeare. The issue here is that most of the words in Shakespeare had a life outside of the plays. Their broader use in the language as a whole is what shapes their meanings, and this then feeds into the specifics of their meanings in Shakespeare (the paper by Culpeper and Findlay on Celtic characters in this special issue illustrates the point). Notes tend to underplay this. Interestingly, linguistics seems to be blamed for the existence of the traditional textual reading approach: it 'has been condemned by some educators as a remnant of philological and linguistic approaches to texts, carried over from Classics departments to the study of English in the early 20th century' (Olive, 2015: 61). Needless to say, linguistics has moved on from the old structuralist approaches of the early 20th century, as our discussion of context and pragmatics above illustrates.

The $21^{\text {st }}$ century has seen a broadening of interest in Shakespeare's language. Moving from the status of recondite academic field of study to a subject of popular interest, books on Shakespeare's language now target more mainstream audiences, often with pedagogical considerations in mind. David Crystal, a fully-fledged linguist, is the major contributor here. One might note his book, Think on my words: Exploring Shakespeare's Language (2012), which in one swoop captures popular interest yet pushes the boundaries of scholarship and is educational. We should also mention his popular Shakespeare's Words website, containing, amongst other things, a glossary for Shakespeare. Furthermore, Keith Johnson's Shakespeare's English: A Practical Linguistic Guide (2014) deserves special mention, because it does more than any other book to engage readers in the practice of learning Shakespeare's language. The important point to note about Keith Johnson, an emeritus professor at Lancaster University, is that he spent a career researching language teaching. His book does not present Shakespeare's plays with a list of glosses for the difficult bits, in just the same way as nobody learning a foreign language today would be presented with simply a text accompanied by a list of notes translating the difficult words. What one gets in Johnson's book, as one would in a language learning class, are texts and explanations but also, crucially, exercises to engage the learner and get them actively practicing linguistic points.

Needless to say, whilst these are positive developments in the textual group, there is certainly room for improvement. We could raise the same question as we did for the other approaches here: are the areas that these books address in fact the ones that students find difficult? Crystal (2012: 10-15) suggests that difficulty largely arises from unfamiliar grammar and vocabulary. Is this correct? Does the inclusion of grammar reflect the fact that he is a linguist with a deeper appreciation of the fact that language is a system? After all, most commentaries and editions focus solidly on words, and the case for words, rather than grammar, is made explicitly by, for example, the translator Kent Richmond (see: http://www.fullmeasurepress.com/pages/FAQ/FalseFriends.html). 
This is the final pre-publication version of: Murphy, Sean, Culpeper, Jonathan and Gillings, Mathew (2020) What do students find difficult when they read Shakespeare? Problems and solutions. Language and Literature 29(3): 302-326. It may contain minor errors or infelicities.

Our study, discussed in the following section, probes exactly what the difficulties are. In the section after that, we will briefly raise the possibility of using a rather different method for teaching Shakespeare's language - the use of corpus-based methods in the classroom. These require the active involvement of learners (both in deploying the method and interpreting the results), treat language in a contextualised fashion, and also focus on the language itself. In other words, they address the kinds of criticism we have been outlining in this section.

\section{Assessing difficulty among first-language and additional-language speakers of English}

\subsection{Method}

\section{Participants}

We conducted a pilot study among three groups of undergraduates in Lancaster (UK), Barcelona (Spain) and Joensuu (Finland). The cohorts comprised 26 English Literature undergraduates at Lancaster University, 28 English Studies undergraduates at the University of Barcelona ${ }^{9}$, and 19 Language and Culture undergraduates including teacher trainee undergraduates at the University of Eastern Finland at Joensuu. Firstly, we selected participants on the basis that they had all studied or were studying one or more Shakespeare plays at the time of the study. Secondly, the three populations represent speakers of English as a first language (Lancaster) and speakers of English as an additional language (Barcelona and Joensuu). The Barcelona participants comprised mostly firstlanguage speakers of Catalan and Spanish (with one Greek and one Turkish exchange student); the Joensuu group were mostly first-language speakers of Finnish (with one Polish and one Czech exchange student). The multilingual Barcelona group offered a particularly interesting point of comparison with the other groups. According to the Common European Framework of Reference for Languages (CEFR), the Joensuu group averaged a B2 level, and the Barcelona group, a higher C1/C2 level of English. ${ }^{10}$ Full ethical clearance was applied for and granted by the Lancaster University Ethics Committee.

\section{Tasks}

We designed three tasks, which were undertaken by all students within each cohort, to evaluate problems students face when reading Shakespeare play-texts. The first two assess how students deal with examples from a variety of plays. The third invites students to express their opinions of Shakespeare's language in general. In this way, we aim to assess both what students actually find difficult and also what they perceive to be problematic.

Our first task, involving a kind of questionnaire, assessed the language forms students found difficult in three prose and three verse extracts of about 80 words each from Shakespeare's comedies, histories and tragedies. In addition, we selected characters of diverse social status. We asked participants to underline anything they found difficult to understand, and to make a note, if possible, of what they thought the underlined word(s) or phrase might mean. Table 1 shows the beginnings and endings of each extract, which for reasons of space cannot be reproduced in full here. 
This is the final pre-publication version of: Murphy, Sean, Culpeper, Jonathan and Gillings, Mathew (2020) What do students find difficult when they read Shakespeare? Problems and solutions. Language and Literature 29(3): 302-326. It may contain minor errors or infelicities.

Table 1. Selected extracts from Shakespeare plays to assess reading difficulty

\begin{tabular}{|c|c|c|}
\hline Play & Character(s) & Extract (V: verse; P: prose) \\
\hline $\begin{array}{l}\text { Richard III (1.2.230- } \\
240)^{11}\end{array}$ & Richard & $\begin{array}{l}\mathrm{V} \text { : Was ever woman in this humour wooed? [...] } \\
\text { And yet to win her! All the world to nothing! }\end{array}$ \\
\hline $\begin{array}{l}\text { Taming of the Shrew } \\
(4.1 .177-185)\end{array}$ & Petruchio & $\begin{array}{l}\text { V: Thus have I politicly begun my reign }[\ldots] \\
\text { That bate and beat and will not be obedient. }\end{array}$ \\
\hline $\begin{array}{l}\text { Henry V (3.6.117- } \\
124)\end{array}$ & Mountjoy & $\begin{array}{l}\text { P: Thus says my king: Say thou to Harry of England }[\ldots] \\
\text { see his weakness, and admire our sufferance. }\end{array}$ \\
\hline Hamlet $(5.1 .15-20)$ & First Clown & $\begin{array}{l}\text { P: Give me leave. Here lies the water }[\ldots] \\
\text { his own death shortens not his own life. }\end{array}$ \\
\hline $\begin{array}{l}\text { King Lear }(1.1 .94- \\
105)\end{array}$ & Lear/Cordelia & $\begin{array}{l}\text { V: How, how, Cordelia! Mend your speech a little }[\ldots] \\
\text { But goes thy heart with this? }\end{array}$ \\
\hline $\begin{array}{l}\text { Much Ado About } \\
\text { Nothing }(3.3 .19-26)\end{array}$ & Dogberry & $\begin{array}{l}\text { P: Well, for your favour, sir, why, give God thanks }[\ldots] \\
\text { you are to bid any man stand, in the Prince's name. }\end{array}$ \\
\hline
\end{tabular}

In our second task, also as part of a questionnaire, we asked students to rate the difficulty (on a 1-5 Likert scale - the higher the score, the greater the difficulty) of particular linguistic forms in 20 sentences from a variety of plays and if possible, state briefly what they mean. Table 2 shows the sentences and linguistic features they exhibit. These test items were drawn from Crystal (2012) and Johnson (2014), who identify them as potentially problematic for students.

Table 2. Sentences containing potentially difficult linguistic features

\begin{tabular}{|l|l|l|}
\hline Play & Item & Linguistic feature \\
\hline Henry V & The vasty fields of France & metrical convenience \\
\hline Hamlet & Woo't weep? Woo't fight? Woo't fast? & archaic vb. + contraction \\
\hline Twelfth Night & no woman has, nor never none & multiple negation \\
\hline Love's labour's Lost & Judas I am, yclept Maccabaeus. & archaic verb \\
\hline Two Noble Kinsmen & You must e'en take it patiently. & contraction \\
\hline Merchant of Venice & Let his deservings, and my love withal & archaic adv./prep. \\
\hline Cymbeline & I have assailed her with musics & plural (now sing.) \\
\hline Henry IV, Part 1 & I tell these news to thee? & concord \\
\hline King Lear & a better where to find & functional shift \\
\hline Henry VI, Part 1 & 'Twas time, I trow, to wake & archaic verb \\
\hline Merry Wives of Windsor & Bless thee, bully doctor! & false friend \\
\hline Titus Andronicus & Gramercy, lovely Lucius & borrowing from French \\
\hline Henry IV, Part 2 & whose chin is not yet fledged & coinage \\
\hline Coriolanus & My words disbenched you not & affixation \\
\hline As You Like It & I would fain see this meeting & archaic adverb \\
\hline Julius Caesar & the people fell a-shouting & a- as particle \\
\hline The Tempest & Well demanded, wench & archaic noun \\
\hline As You Like It & a properer man & comparative \\
\hline & & \\
\hline
\end{tabular}


This is the final pre-publication version of: Murphy, Sean, Culpeper, Jonathan and Gillings, Mathew (2020) What do students find difficult when they read Shakespeare? Problems and solutions. Language and Literature 29(3): 302-326. It may contain minor errors or infelicities.

\begin{tabular}{|l|l|l|}
\hline The Tempest & The mistress which I serve & grammatical change \\
\hline Romeo and Juliet & So early walking did I see your son & word order \\
\hline
\end{tabular}

Our third task consisted of focus groups. Focus groups might be described as group interviews. Whereas a survey presents informants with test items and questions preselected by researchers, focus groups, with broad questions as prompts, enable researchers to tease out the issues (including issues that they had not thought to probe in a survey) with relatively little bias. Focus groups elicit rich data, though a downside of that is that focus group studies tend to have relatively few informants (to take but one example, Burt (2015), studying terms of address uses a total of 18 participants). Focus groups vary in size, Nyumba et al. (2018), surveying the use of focus groups in ecology studies, found that they varied from 3 to 21 participants, with a median of 10 . We split our informant cohorts up into focus groups varying between 3 and 5 participants. The reason for the smaller size of the focus group was to give undergraduates more confidence in speaking within their group. An innovation we adopted here is the use of an online discussion tool called 'Padlet' (https://padlet.com). We projected open questions (see Figure 1) and asked students to discuss them in groups of three and make notes.

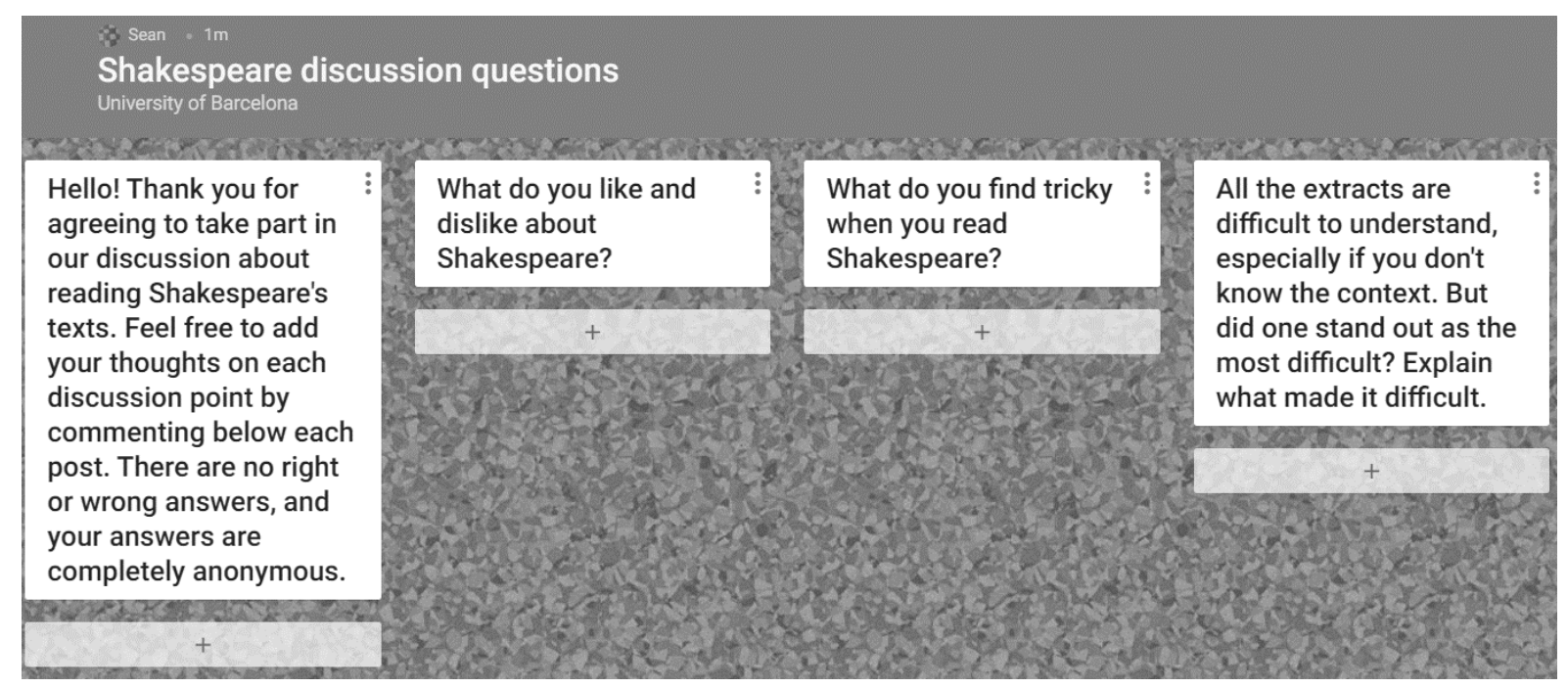

\section{Figure 1. Shakespeare discussion questions on Padlet.}

After 15 minutes, we provided them with a QR code to access the Padlet discussion space via their smartphones and to add their notes below each question. All contributions appeared immediately so they were able to comment on other groups' contributions, all of which were anonymous. The Padlet tool facilitates the export of resulting data for analysis. The Padlet discussion proved popular and obviated the need for audio transcription of students' discussions.

\subsection{Findings and discussion for individual tasks}

In this section, we present the findings of each task individually. The following section, Section 3.3, offers a brief summary of them all. 
This is the final pre-publication version of: Murphy, Sean, Culpeper, Jonathan and Gillings, Mathew (2020) What do students find difficult when they read Shakespeare? Problems and solutions. Language and Literature 29(3): 302-326. It may contain minor errors or infelicities.

Task 1

Figure 2 shows the average number of words or expressions underlined per play extract.

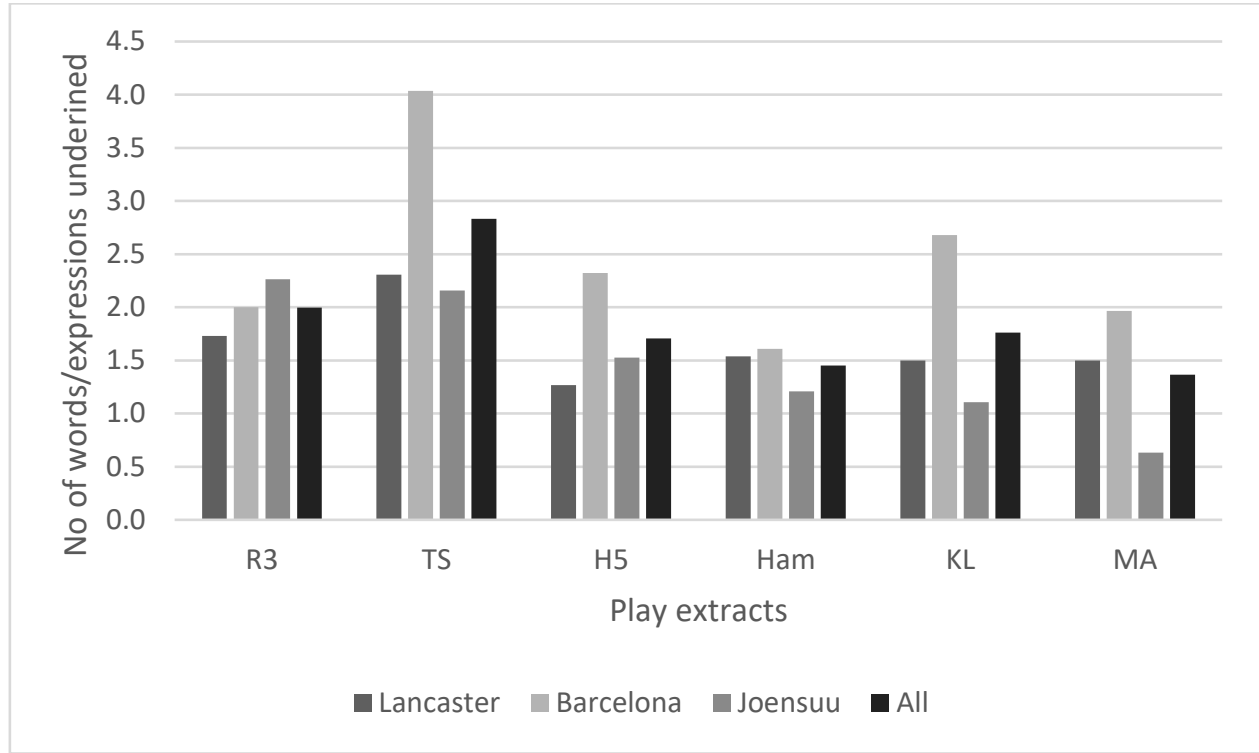

Figure 2. Participants' appraisal of difficulty of play extracts by number of underlined words/expressions (Task 1).

Students found the Taming of the Shrew extract to be the most difficult, with the Barcelona participants in particular finding this extract problematic. Students cited the use of metaphor, lack of context and difficult vocabulary in this extract as impediments to comprehension. This first-language speaker's comment echoed those of many:

The Taming of the Shrew was the most difficult because none of [the] sentences cohere or make sense as whole. They don't seem linked and the language used is language we are familiar with but not used in the same sense. ie. I thought 'Falcon' was a bird. It's clearly not a bird in this context.

Clearly, some information regarding context is essential to understanding. The following comment from an additional-language speaker reinforces the point:

The [extract] taken from Richard III, we feel like we would need some context for that fragment. What confuses us are specially the first two lines; he uses 'wooed' and 'won' and it is confusing because we can't understand if he is happy, sad, mad... How is the character feeling?

It might be argued that, to a certain extent, students' understanding was impaired by the method: being presented with de-contextualised extracts, they lacked contextual information about the fictional world of the play, including knowledge of the characters. Had they known, for example, that Petruchio seemingly intends to 'tame' Katherine, they might have understood the Taming of the Shrew extract better. We would argue that such general contextual information, whilst it can indeed provide additional interpretative clues, 
This is the final pre-publication version of: Murphy, Sean, Culpeper, Jonathan and Gillings, Mathew (2020) What do students find difficult when they read Shakespeare? Problems and solutions. Language and Literature 29(3): 302-326. It may contain minor errors or infelicities.

in many cases will not provide sufficient help at a local level of comprehension in dealing with completely unknown word-meanings, shades of difference between meanings, difficult to parse sentences, and so on. Zirker et al. (forthcoming: 9), studying the whole of sonnet 43, is consistent with this line of argument. A student in their study is reported as commenting: "I don't understand the word 'wink' in this context". Failure to understand the local context of the first line containing a paradox would endanger understanding of the rest of the sonnet. The authors suggest, when discussing these local contextual issues, that "a certain level of comprehension is necessary in order to be able to identify gaps in one's own comprehension" (Zirker et al. forthcoming: 9).

Table 3 displays the particular linguistic items that participants most frequently identified as problematic in the six extracts in Task 1 . The extracts are rank-ordered in terms of the number of underlined words and phrases, Taming of the Shrew having the most.

Table 3. Participants' most underlined forms (Task 1)

\begin{tabular}{|c|c|}
\hline $\begin{array}{l}\text { Taming of } \\
\text { the Shrew }\end{array}$ & $\begin{array}{l}\text { - And till [my falcon] stoop she must not be full-gorged, } \\
\text { - Another way I have to man my haggard }\end{array}$ \\
\hline King Lear & $\begin{array}{l}\text { - Mend your speech a little / Lest you may mar your fortunes. } \\
\text { - Good my lord, / You have begot me, bred me, loved me }\end{array}$ \\
\hline Richard III & $\begin{array}{l}\text { - Was ever woman in this humour wooed? } \\
\text { - But the plain devil and dissembling looks? }\end{array}$ \\
\hline Hamlet & $\begin{array}{l}\text { - If the man go to this water / and drown himself, it is, will he nill he, he goes } \\
\text { - Argal, he that is not guilty of / his own death shortens not his own life. }\end{array}$ \\
\hline $\begin{array}{l}\text { Much Ado } \\
\text { About } \\
\text { Nothing }\end{array}$ & $\begin{array}{l}\text { - You are thought here to be the most senseless and fit man for the constable of } \\
\text { the watch } \\
\text { - This is your charge: you shall comprehend all vagrom men }\end{array}$ \\
\hline Henry $V$ & $\begin{array}{l}\text { - Tell him we could have rebuked him at Harfleur, but that we thought not good } \\
\text { to bruise an injury till it were full ripe }\end{array}$ \\
\hline
\end{tabular}

We have already mentioned the falconry terms such as 'full-gorged [allowed to eat her fill]' and 'haggard [wild hawk]' in The Taming of the Shrew. Other difficulties students most often identified in the extracts were: archaisms ('begot', 'wooed'); items infrequently used in present-day English ('mar', 'dissembling'); colloquial language ('will he nill [will not] he' - the origin of the present-day expression 'willy nilly'); malapropisms ('Argal [Latin 'Ergo']', 'vagrom [vagrant]'); culturally contemporary references ('constable of the watch'); and false friends ('rebuked [supressed]', 'full ripe [completely ready]'). Despite 
This is the final pre-publication version of: Murphy, Sean, Culpeper, Jonathan and Gillings, Mathew (2020) What do students find difficult when they read Shakespeare? Problems and solutions. Language and Literature 29(3): 302-326. It may contain minor errors or infelicities.

the relative predictability of such results, they confirm a need to address these particular linguistic areas when helping students.

We also checked to see whether any differences in our results could be attributed to the distinction between verse and prose. Figure 3 shows that all three groups underlined more forms and therefore encountered greater difficulties in the verse extracts, although the discrepancy was less marked for the first-language speakers from Lancaster. However, in task 3, only one of the 73 participants commented specifically on the difficulty of understanding verse, saying 'Things in blank verse make it harder to read'. It may well be the case that students are simply unaware that difficulties arise in part from the poetic demands that writing in verse enforces the dramatist to make, such as whether to use a particular word to fit the metre, use elision or a marked word order. This clearly merits more detailed investigation.

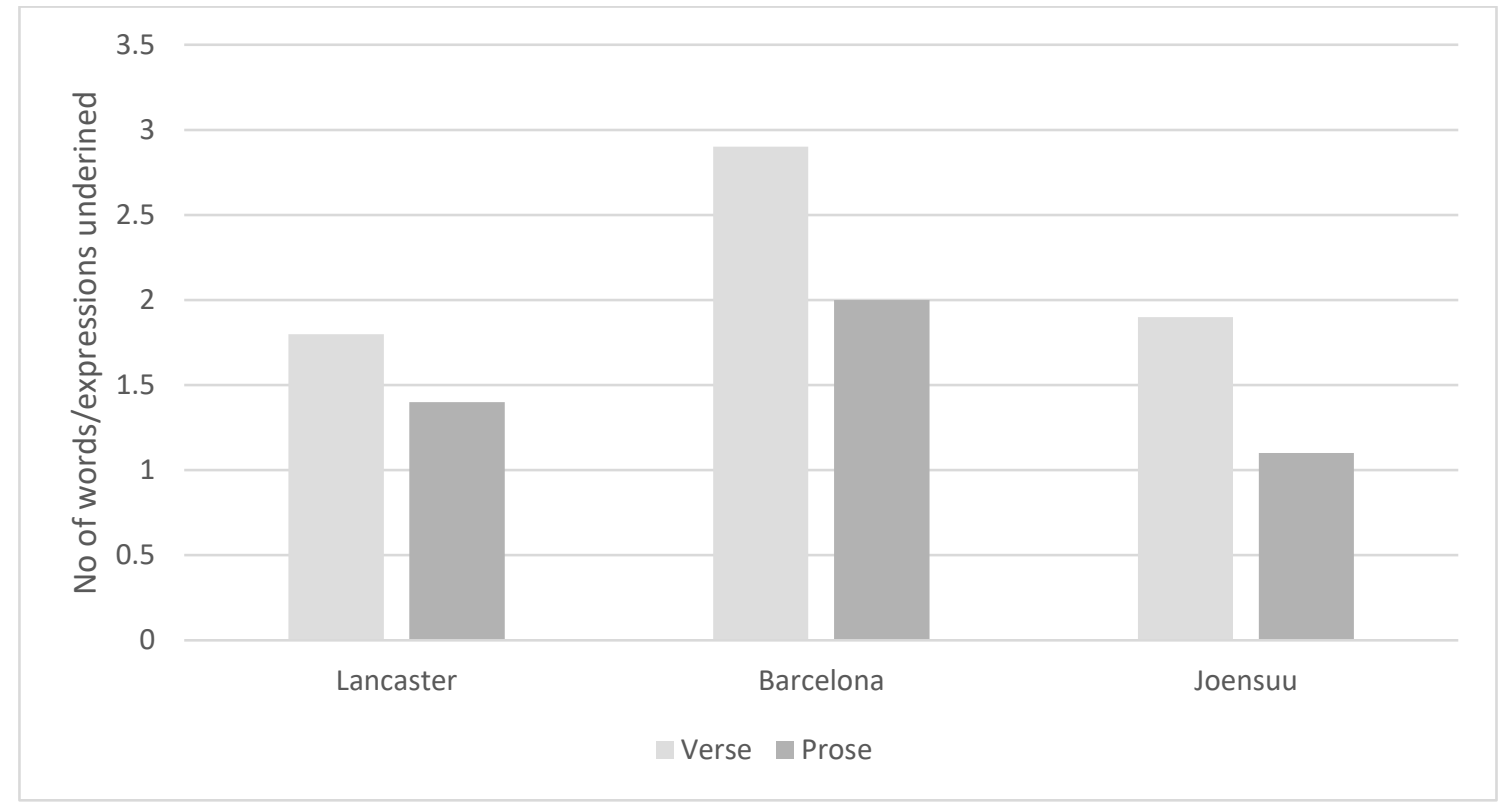

Figure 3. Participants' appraisal of difficulty of play extracts by verse and prose (Task 1).

Task 2

The graph in Figure 4 displays the comprehensibility of the linguistic forms presented in Table 2 (Section 3.2) for participants. The lines for all three groups follow a similar pattern, suggesting comparable levels of understanding. 
This is the final pre-publication version of: Murphy, Sean, Culpeper, Jonathan and Gillings, Mathew (2020) What do students find difficult when they read Shakespeare? Problems and solutions. Language and Literature 29(3): 302-326. It may contain minor errors or infelicities.

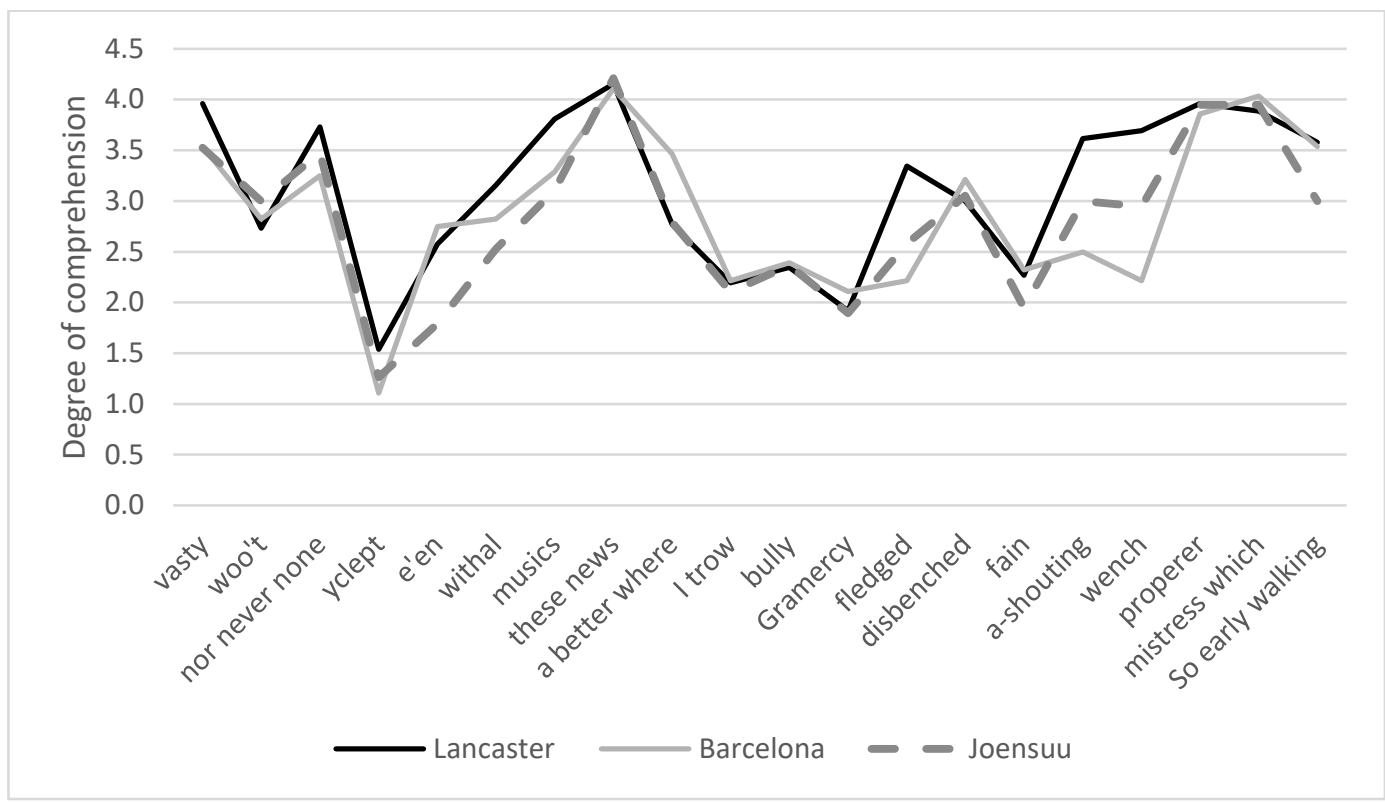

Figure 4. Participants' appraisal of the difficulty of particular linguistic features (Task 2)

For all groups, the most problematic features in rank order include: archaisms ('yclept [called]', 'fain [gladly]', 'I trow [I guess]'); contractions ('e'en [even]); false friends ('bully' [good friend]); coinages ('fledged' [showing hair growth]); and borrowings (Gramercy' [great thanks]). Interestingly though, where lines diverge slightly, we see that additional-language students found the functional shift in 'a better where' and grammatical change in 'mistress which' (in present day English 'mistress who/that') marginally less problematic than first-language speakers did. Both of these forms might be regarded as 'mistakes' by present-day first-language speakers, yet may be more easily interpretable by additional-language speakers as a result of L1 influence. That said, other 'non-standard' features such as multiple negation ('nor never none') caused greater problems of comprehension, while non-standard comparatives ('properer') or issues of concord ('these news'), caused fewer comprehension problems. First-language-speaker participants appeared to understand 'a-shouting' and 'wench' better than additional-language speakers did. However, they might have been unaware that in Shakespeare, 'wench' invariably refers simply to a girl or young woman, without the derogatory connotations of some present-day usage.

\section{Task 3}

In many ways, the third task elicited some of the most interesting data as participants expressed themselves freely on what they liked and disliked about Shakespeare, and what they find tricky when they read Shakespeare. Table 4 summarises the most common responses students gave. 
This is the final pre-publication version of: Murphy, Sean, Culpeper, Jonathan and Gillings, Mathew (2020) What do students find difficult when they read Shakespeare? Problems and solutions. Language and Literature 29(3): 302-326. It may contain minor errors or infelicities.

Table 4. Participants' opinions expressed in discussion via Padlet (Task 3).

\begin{tabular}{|c|c|c|c|}
\hline & Lancaster & Barcelona & Joensuu \\
\hline $\begin{array}{l}\text { What do you } \\
\text { like and dislike } \\
\text { about } \\
\text { Shakespeare? }\end{array}$ & $\begin{array}{l}\text { Like } \\
\text { innovative, creative, } \\
\text { complex - makes you think } \\
\text { plots and characters } \\
\text { language - poetic, } \\
\text { eloquent, natural, creative, } \\
\text { prestigious } \\
\text { universality, moral } \\
\text { message } \\
\text { Dislike } \\
\text { wordy, lengthy, } \\
\text { convoluted - hard work } \\
\text { context-dependent } \\
\text { outdated language / jokes / } \\
\text { references } \\
\text { miss out on humour } \\
\text { pronunciation changes }\end{array}$ & $\begin{array}{l}\text { Like } \\
\text { plots and character } \\
\text { construction } \\
\text { locations } \\
\text { identification with themes } \\
\text { and characters } \\
\text { universality } \\
\text { Dislike } \\
\text { overcomplicated, } \\
\text { pretentious, pedantic } \\
\text { overexposed, overrated } \\
\text { complex/archaic language } \\
\text { difficulty }\end{array}$ & $\begin{array}{l}\text { Like } \\
\text { plots and characters } \\
\text { relevant themes } \\
\text { open to adaptation } \\
\text { good humour }\end{array}$ \\
\hline $\begin{array}{l}\text { What do you } \\
\text { find tricky } \\
\text { when you read } \\
\text { Shakespeare? }\end{array}$ & $\begin{array}{l}\text { (archaic) language } \\
\text { apostrophes used for } \\
\text { elision punctuation } \\
\text { metaphors and idioms } \\
\text { meanings same as present- } \\
\text { day? } \\
\text { word order } \\
\text { word play } \\
\text { pronunciation changes } \\
\text { grammar }\end{array}$ & $\begin{array}{l}\text { (archaic) language } \\
\text { historical and classical } \\
\text { references } \\
\text { metaphors } \\
\text { (long) sentence structure }\end{array}$ & $\begin{array}{l}\text { difficult vocabulary } \\
\text { change in meaning } \\
\text { aspects of grammar }\end{array}$ \\
\hline
\end{tabular}

Many of the general aspects students liked are familiar: plots, characters, themes and universality. Similarly, the most commonly expressed dislike concerned the complexity of the language. It is worth quoting some of students' comments on language in full to appreciate the range of views. A considerable number of remarks on Shakespeare's language were very positive: 'When I read Shakespeare I feel like through the language it creates a whole new world'. The following comments reveal an appreciation of ambiguity and linguistic elegance: 'What I like about Shakespeare is that he uses double meaning'; 'What I like [about] Shakespeare is his way of expressing his thoughts in a very sophisticated way'. Some students expressed mixed feelings: 'I like the atemporality of his plays and his capacity and magestry [mastery] to change from drama to comedy. He transmits powerful images and sensations despite the language used'; 'We like the poetic language used, the elaborate vocabulary in it; we specially like tragedies because we enjoy the intense feelings in them. We dislike the archaic language as the comprehension of the text becomes much harder.' Clearly, while students may admire the language, they feel it can represent an obstacle to enjoyment.

Negative comments on Shakespeare's language were particularly prevalent among additional-language speakers: 'The vocabulary, the structure, the language itself difficults [hinders] the comprehension. Moreover, being a non-native speaker is even more difficult. If reading Don Quijote for example is already complicated, Shakespeare is even worse'; 'As a NNS [additional-language speaker] of English I find the language difficult not only certain words but also some long sentences because they are so complex that sometimes I 
This is the final pre-publication version of: Murphy, Sean, Culpeper, Jonathan and Gillings, Mathew (2020) What do students find difficult when they read Shakespeare? Problems and solutions. Language and Literature 29(3): 302-326. It may contain minor errors or infelicities.

have to read one passage multiple times to understand the meaning'. Perhaps such comments reflect insecurities as additional-language speakers, although first-language speakers have similar insecurities, sometimes regarding Shakespeare as written in a foreign language. Other students pointed to particular stylistic aspects of the language which they found problematic: 'We are not fond of his writing style because he overcomplicates sentence structure and vocabulary use'; 'We dislike the fact that he uses vocabulary and rhetorical devices that are difficult to understand'; 'He uses a language that is quite archaic and difficult, not only the vocabulary but also the use of metaphors'. Comments such as these were frequently expressed. In one case, a younger student even felt the language has an unreal quality: 'Some of the words don't seem like real words.' There was even some anti-Shakespeare feeling among the additional-language speakers: 'I think Shakespeare is overrated. I think it's unfair because he eclipses other authors that also deserve to be recognised'; 'we as students are overexposed to him [Shakespeare], forced to put the same overrated value on his work as some 'academics' with whom we might not agree have done.'

The trickiest aspects of language frequently identified by participants were, in rank order: lexis, semantic change and complex syntax. Participants offered the following opinions: 'usually the most necessary and specific vocabulary is the one we cannot understand'; 'Maybe a word meant something at the time and now, as language evolves, it could mean something else'; 'long sentences because they are so complex that sometimes I have to read one passage multiple times to understand the meaning.' What is encouraging here is that students are both aware of the nature of their linguistic difficulties and willing to persevere. This would suggest that targeted help with specific linguistic areas could prove effective. Another problematic area was apostrophising: 'when he [Shakespeare] uses apostrophes to shorten words that aren't typically shortened nowadays it can be confusing.' Some students also mentioned cultural references as a source of difficulty: 'We find quite tricky that readers need a lot of previous knowledge about the history of Britain and the Classic Greece and Rome to understand the meaning and the context of Shakespeare's stories.' Interestingly, not all additional-language students agreed on this point, at least as far as classical references were concerned: 'sometimes people from Spain, Turkey or around the Mediterranean Sea have better knowledge about the Classic references from the Greek Tragedies'. This might suggest some form of diagnostic activity to ascertain students' knowledge of cultural references would be worthwhile.

\subsection{Summary of all findings}

One of the most notable findings was the similarity of results for speakers of English as a first or additional language. We might have expected that our additional language speaker cohorts would have expressed much greater difficulty understanding Shakespeare's language than the first-language group. The similarity of results among the groups would suggest that broadly speaking, high-level additional-language speakers encounter the same kinds of difficulties as first-language speakers do. That said, some minor discrepancies are apparent and we comment on them in Section 4.

We have also provided evidence for what one might expect: verse is generally harder for students, though somewhat less hard for the students from England. Each task provided some detail about the areas students find particularly difficult. In Table 5, we present these in rank order. These are key areas teachers might wish to focus on. 
This is the final pre-publication version of: Murphy, Sean, Culpeper, Jonathan and Gillings, Mathew (2020) What do students find difficult when they read Shakespeare? Problems and solutions. Language and Literature 29(3): 302-326. It may contain minor errors or infelicities.

Table 5. Summary of difficulties in rank order

\begin{tabular}{|l|l|l|}
\hline \multicolumn{1}{|c|}{ Extracts } & Individual items & Self-reported \\
\hline$\bullet$ use of metaphor & $\bullet$ archaisms & $\bullet$ lexis \\
$\bullet$ lack of context & $\bullet$ contractions & $\bullet$ semantic change \\
$\bullet$ difficult vocabulary & $\bullet$ false friends & $\bullet$ complex syntax \\
& $\bullet$ coinages & $\bullet$ cultural references \\
\hline
\end{tabular}

\section{Teaching and learning: A glance at corpus-related possibilities}

As explored in Section 3.2, it is clear that whilst students experience and are aware of the varied linguistic difficulties they face when reading Shakespeare's language, they are still willing to persevere. Both of these factors bode well within the context of our earlier discussion regarding the importance of active learning within the classroom, especially given the need for learners to buy into and engage with a text in order to truly understand it. Starting with the summary of difficulties our participants encountered (see Table 5), it is possible to offer targeted help and support to aid students' understanding of Shakespeare's texts. However, rather than focussing exclusively on performance to achieve this, we propose a textual approach - a pedagogical corpus stylistic approach - which can be used in a complementary fashion with performance and broader (e.g. socio-cultural) contextual approaches.

Advocated by McIntyre and Walker (2019), pedagogical corpus stylistics combines the application of stylistic techniques to teaching language with corpus linguistic methods such as concordancing and collocation. Stylistics can heighten students' language awareness and help them to engage with difficult texts (Clark and Zyngier, 2003), as well as encouraging them to appreciate certain linguistic choices (Shen, 2012). A pedagogical corpus stylistic approach requires the active involvement of learners on both a methodological and an analytical / interpretative level. It starts from the premise that corpora should be interrogated by language learners because corpora are good repertoires of natural language usage. By natural language usage, we mean not constructed by the writer to illustrate a point they are trying to make (something generative linguists and linguists from the past often did). Learners are not only able to view words in context, through the use of concordancers, but they can also employ techniques that are more complex too, such as collocation analysis (that is, the identification of regularly cooccurring words). Both concordance and collocation analysis allow learners to better understand the specific semantic nuances of words, or the specific contexts in which they are or are not used. Allowing learners to see which words occur alongside a particularly problematic term, for example, may give them the knowledge and confidence to form their own hypotheses as regards to meaning. In addition, the use of a multi-genre corpus, as for example produced by the Encyclopedia of Shakespeare's Language project, enables one to see through frequencies of occurrence whether words or structures have an affinity for certain genres. The word bastard, for example, was not the colloquial word of today, but primarily a technical word used in instructional treatises, especially on botany, for hybrid species. It can also afford insights into whether Shakespeare's language patterns simply reflect the 'poetic' or 'dramatic' language of the day, or are creatively exploiting contemporary conventions. 
This is the final pre-publication version of: Murphy, Sean, Culpeper, Jonathan and Gillings, Mathew (2020) What do students find difficult when they read Shakespeare? Problems and solutions. Language and Literature 29(3): 302-326. It may contain minor errors or infelicities.

Applying corpus methods in this way is by no means a new endeavour, with work as early as 2004 (e.g. Sinclair, 2004; Aston et al., 2004) advocating the use of computerassisted methods to learn language within the classroom. Not only does this approach encourage students to take active responsibility for their learning, but it also allows students to see for themselves how language works within context. This well-researched and well-supported method discussed above is known as data-driven learning (DDL), which may be 'located on a cline ranging from teacher-led to learner-led' (Gilquin and Granger, 2010: 363). In other words, DDL can either be carried out purely by students with no teacher intervention, or in a fully-supported manner to aid learning. The approach includes an 'element of discovery' which boosts the learners' confidence and self-esteem; they make the decision about what they want to investigate, and how they want to go about it (Gilquin and Granger, 2010: 359), but can be achieved with differing degrees of teacher input. The method is traditionally applied to students learning English as a second or foreign language, but those same methods can also be applied to learning other varieties of the same language - in this case, Early Modern English within the works of Shakespeare. Kettemann and Marko (2004) offer an early exploration of how corpus-based methods may be applied to literature - in fact, they feature a short analysis of speech acts and performative verbs in Shakespeare's plays - concluding that concordancing can help students in their explorations of texts, either prior to or after a first reading. This is exactly the approach we advocate, including through the use of resources made available through the Encyclopedia of Shakespeare's Language project.

Many of the difficulties identified throughout this study could be alleviated, at least in part, through the use of corpus-based methods. Revisiting Table 5, it is clear that difficult vocabulary, archaisms, false friends, coinages, lexis, semantic change, and to some extent lack of context can all be approached through the use of corpus-based methods, utilising both concordancing and collocation analysis to support learning. We have selected two of our test items - fain and nor never none - to demonstrate how the former method could be useful to students in the classroom who are having difficulties.

We emphasise at the outset that we recommend the following text-based discovery approach be teacher-guided and, if possible, used in conjunction with a performance-based and broader context-based approaches. Having provided basic instruction in how to perform simple and restricted searches with CQPweb, teachers can ask students to investigate the use of fain by searching for the term in the Enhanced Shakespearean Corpus: Folio Corpus, one of the resources produced by the Encyclopedia of Shakespeare's Language Project, via the web-browser program CQPweb (https://cqpweb.lancs.ac.uk; see Hardie, 2012) (all project resources are available from the project website: http://wp.lancs.ac.uk/shakespearelang/). Fain occurs in 27 of the 38 plays in our corpus, and a quick search reveals 69 matches. By displaying all instances in a linear fashion, learners can visualise data easily in their quest for meaning. Glancing down the lines, the learner will probably notice that the word would is a frequent collocate, usually before fain. Learners can then sort the lines by words 1 position to the left of fain. This will reveal that 35 of the 69 instances contain would fain (with 2 instances of ' $d$ fain, and 10 instances of fain would). Students can be directed to the 'Choose action' drop-down menu and select the 'Collocations' option. Clicking on 'Create collocation database' on the following screen will confirm that would is the most frequent collocate of fain. The learner will also see that the other two most frequent collocates are have and $I$. Figure 4 shows a sample of the results for the collocate $I$, sorted by the second word to the left. 
This is the final pre-publication version of: Murphy, Sean, Culpeper, Jonathan and Gillings, Mathew (2020) What do students find difficult when they read Shakespeare? Problems and solutions. Language and Literature 29(3): 302-326. It may contain minor errors or infelicities.

14 Ham Ham_2_2 Ham_Claudius:As of a man, faithful and Honourable.Ham_Polonius:I would fain prove so . But what might you think ? When I had

15 MA MA_3_5 glad to hear it.MA_Verges:And so am I.MA_Leonato:I would fain know what you have to say.MA_Verges:Marry sir our watch tonight

16 TC TC_3_1 Antenor, and all the gallantry of Troy. I would fain have armed today, but my Nell would not have it so

17 AYLAYL_3_3 place of the Forest , and to couple us. AYL_Jaques:I would fain see this meeting .AYL_Audrey:Well , the Gods give us joy

18 TCTC_54

's Sleeve of Troy, there in his Helm : I would fain see them meet ; that , that same young Trojan ass,

19 H can be desired in the hearts of his Subjects : I would fain see the man , that has but two legs , that shall

\section{Figure 5. A sample of concordance lines from the ESC: Folio for the word fain showing frequent collocates would and $I$}

By reading the concordance lines (and through viewing the additional context by clicking the node word), the learner gets a feel for what is happening within the context of each use. To take an example from Figure 5 above, in line 15, Leonato in Much Ado says 'I would fain know what you have to say'. Clicking on fain takes the learner to the context in the play. Verges replies to Leonato by offering information, leading the learner to hypothesise that fain in this context might mean something like 'really like to'. The learner can then test that hypothesis on other instances. The value of this inductive approach is not only that learners are given the chance to infer meaning from concordance lines, but are exposed to common collocational patterns, thus aiding them as they expand their reading of Shakespeare's plays.

On a more nuanced level, or simply to retrieve a wider array of examples and affirm patterns, learners can use a corpus like Early English Books Online (EEBO) - a corpus consisting of over a billion words, consisting of virtually every work printed in English from 1473-1700 - to track the journey of semantic change year-by-year. One resource created by the Encyclopedia of Shakespeare's Language Project is a specially curated and enhanced portion of EEBO, the ESC: EEBO-TCP Segment (see Murphy, 2019). This allows a better understanding of Shakespeare's language through an examination of how words were generally used in his time. Building on the knowledge that would is a common collocate of fain, students can use the Enhanced Shakespearean Corpus: EEBO-TCP Segment to see how Shakespeare's usage of would fain / fain would compares with the period in which he was writing (approximately 1590-1615), through a process of guided discovery, Students can be provided with a version of Table 6 in which the underlined information is missing and they use corpus searches to provide it.

Table 6. Comparison of would fain / fain would in Shakespeare and Early English Books Online (EEBO)

\begin{tabular}{|c|c|c|c|c|}
\hline $\begin{array}{l}\text { would fain / fain } \\
\text { would }\end{array}$ & Shakespeare & $\begin{array}{l}\text { Most frequent } \\
\text { collocates } \\
\text { (number of } \\
\text { instances) }\end{array}$ & $\begin{array}{c}\text { EEBO: TCP- } \\
\text { Segment restricted } \\
\text { query } 1590-1615\end{array}$ & $\begin{array}{l}\text { Most frequent } \\
\text { collocates } \\
\text { (number of } \\
\text { instances) }\end{array}$ \\
\hline $\begin{array}{c}\text { Relative } \\
\text { frequency } \\
\text { (instances per } \\
\text { million words) }\end{array}$ & $\underline{33.702}$ & I ( $\underline{21})$, have ( $\underline{12})$ & $\underline{29.097}$ & I (869), have (751) \\
\hline
\end{tabular}


This is the final pre-publication version of: Murphy, Sean, Culpeper, Jonathan and Gillings, Mathew (2020) What do students find difficult when they read Shakespeare? Problems and solutions. Language and Literature 29(3): 302-326. It may contain minor errors or infelicities.

\begin{tabular}{|c|c|c|c|c|}
\hline $\begin{array}{l}\text { Typical patterns } \\
\text { and relative } \\
\text { frequency } \\
\text { (instances per } \\
\text { million words) }\end{array}$ & $\begin{array}{l}\text { I would fain }(\underline{18.295}) \\
\text { fain would I }(\underline{4.815})\end{array}$ & $\begin{array}{l}\text { I would fain see } \\
\text { fain would I go }\end{array}$ & $\begin{array}{l}\text { I would fain }(\underline{7.791}) \\
\text { fain would I }(\underline{2.088})\end{array}$ & $\begin{array}{l}\text { I would fain know } \\
\text { fain would I know }\end{array}$ \\
\hline
\end{tabular}

In this way, not only are students exposed to many more examples of would fain / fain would, but they can make deductions as to the stylistic reasons why, for example, relative frequencies of would fain / fain would are higher in Shakespeare than in other contemporary texts. In fact, the ESC: EEBO-TCP Segment reveals that the highest relative frequencies occur in the genres PoetryVerseSong (111 instances per million words) and Fiction (96 instances per million words), suggesting that fain was predominantly a literary word.

Similarly, teachers can encourage learners to investigate the meaning of structures containing multiple negation as in Viola's 'I have one heart, one bosom, and one truth, / And that no woman has, nor never none / Shall mistress be of it, save I alone' (Twelfth Night, 3.1). Having discussed the effect of piling up negatives in this way, learners might be encouraged to use the ESC: Folio corpus to check to see if there are other instances of multiple negation with three negative forms using the search string $n+n+n+($ the + denoting 1 or more letters). Figure 6 shows the results of this search string.

\begin{tabular}{|c|c|c|c|c|}
\hline 1 & $\underline{K L} K L \_2$ & a Lady; If only to go warm were gorgeous, Why & Nature needs not & what thou gorgeous wearst, Which scarcely keeps thee warm , but \\
\hline 2 & $\underline{\text { Mac Mac_1_3 }}$ & Card .I'll drain him dry as Hay : Sleep shall & neither Night nor & Day Hang upon his Penthouse Lid : He shall live a man \\
\hline 3 & $\underline{\text { MM MM_1_1 }}$ & Spirits are not finely touched, But to fine issues: & nor nature never & lends The smallest scruple of her excellence, But like a thrifty \\
\hline 4 & MND MND_2_2 & it not enough, young man, That I did never, & no nor never & can , Deserve a sweet look from Demetrius ' eye, But \\
\hline 5 & RJ RJ_4_2 & Nurse.RJ_CapuletsWife:We shall be short in our provision, $\mathrm{T}$ is & now near night & RJ_Capulet:Tush, I will stir about, And all things shall \\
\hline 6 & TNTN_3_1 & bosom, and one truth, And that no woman has, & nor never none & Shall mistress be of it, save I alone. And so \\
\hline 7 & 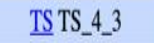 & charity : But I, who never knew how to entreat, & Nor never needed & that I should entreat, Am starved for meat, giddy for \\
\hline
\end{tabular}

Figure 6. Concordance lines for the search string $n+n+n$ in the ESC: Folio.

It will be immediately obvious to learners that only instance 4, Helena's 'I did never, no nor never can, / Deserve a sweet look from Demetrius' eye' (Midsummer Night's Dream, 2.2), parallels, and indeed trumps Viola's example with four consecutive negatives. There is not the space here to expand on the numerous ways in which such explorations might develop. Suffice it to say that these resources offer learners and teachers multiple opportunities to explore and make connections in their discovery of Shakespeare's language.

What we have demonstrated above is the utility of applying corpus-based methods to the study of literature within the classroom. However, it should be noted that whilst concordance, and indeed collocation, analysis provide a good first step, there are other techniques available to the user to support their learning too. For example, learners may wish to use a reference corpus of modern-day English, such as the British National Corpus (BNC), to investigate how a word's meaning has changed over time. Within the context of our earlier discussion, one could swiftly search for the word wench in the ESC: Folio, and then again in the BNC, to investigate how its meaning has differed. The methods outlined 
This is the final pre-publication version of: Murphy, Sean, Culpeper, Jonathan and Gillings, Mathew (2020) What do students find difficult when they read Shakespeare? Problems and solutions. Language and Literature 29(3): 302-326. It may contain minor errors or infelicities.

in this section involve the learner in the text; they encourage the learner to actively participate and thereby soak up the nuances of meaning - an experience that one does not get from a simple dictionary.

One particular limitation of using corpus-based methods in the classroom, which it also shares with the performance approaches discussed above, is that it can be timeconsuming. Whilst there is an emerging body of work (e.g. Liu, 2019) indicating that corpus-based approaches improve writing practices over time (and they do so more effectively than unsupported learning or a thorough use of a collocations dictionary), teaching students how to use and interpret these tools can take time - even before independent analysis and interpretation gets underway. In addition, this method does not address everything. Readers may note that out of the 12 main difficulties that learners encounter within the works of Shakespeare (see Table 5), there still remain some that the corpus-based method can do less to help with. Grammatical or syntactic difficulties, for example, would require a more complex approach. There are ways in which one could use grammatical part-of-speech tagging to investigate functional conversions, complex syntax, and negation, but actually taking syntactic structures apart via these methods would be pedagogically difficult (and most likely ineffective). These affordances may be useful for researchers, but perhaps not for learners. It is clear that there is not a single solution for everything, but the corpus-based approach solves some of the problems associated with textual approaches: it keeps students active in the learning process, engages them, and encourages them to take responsibility for their learning.

\section{Discussion and conclusions}

As we have made repeatedly clear, it has certainly not been the aim of this article to extol the virtues of adopting textual approaches only. Active or performance approaches can inject life into the classroom. Moreover, they take account of the fact that plays were written for performance. Regarding meaning, such approaches embody paralinguistic aspects - the stress, rhythm or metre of the lines, the tempo and pausing (partly signalled by the punctuation), the intonation, and so on, not to mention nonverbal aspects, such as gaze direction facilitating turn-taking. Such performances can and do offer clues about how to interpret the lines. Ultimately, however, they offer limited help with some of the core aspects of language, notably, vocabulary and grammar. Contextual approaches also have a part to play, just as in language learning scholars argue that pragmatics should be part of what is taught from the very beginning. They help us avoid anachronistic interpretations, and, moreover, help reveal nuances and resonances of meaning, for example, by highlighting the socio-cultural contexts of use. Ultimately, however, they too offer limited help with the core aspects of language. In the world of second language pragmatics teaching, the assumption is that pragmatic/contextual aspects proceed alongside linguistic/textual aspects. Moreover, our findings suggest that the key issue for students is comprehension in the local context, not nuances and resonances that are afforded by broader perspectives (see also Zirker et al. forthcoming).

Compared with active/performance and contextual approaches, textual approaches have, stereotypically, proceeded with minimal creativity. If the received wisdom is to use a good edition, replete with footnotes, and proceed line-by-line with the additional aid of glosses provided by a teacher, then this does not bode well for learning. Of course, as we pointed out, not every textual approach is so traditional, but they do seem to be a minority. With a mere handful of exceptions, what has generally 
This is the final pre-publication version of: Murphy, Sean, Culpeper, Jonathan and Gillings, Mathew (2020) What do students find difficult when they read Shakespeare? Problems and solutions. Language and Literature 29(3): 302-326. It may contain minor errors or infelicities.

been ignored are approaches informed by research on language teaching. A starting point for any such approach must be a better understanding of what students actually find difficult.

The study we reported in this paper seems to be one of the first - if not the first - to provide empirical evidence as to what students find difficult when they read Shakespeare's plays. It also took the important step of taking into consideration both first-language and additional-language speakers, because as we have argued, interest in Shakespeare is a global phenomenon. The most difficult area of study turned out to be words: unknown or unfamiliar words, and words that have shifted in meaning. This vindicates, to some extent, the vast efforts that have been put into translating words in the footnotes of editions, and also producing dictionaries and glossaries. However, our study also indicated the importance of other areas, notably, complex syntax, metaphor and incomplete cultural knowledge. Differences between first-language and additionallanguage speakers were few. Occasionally, some informants with English as an additional-language found that their first-language Catalan or Spanish gave them a better way into understanding early modern English than present-day English. Being multilingual, and in particular having a knowledge of French, Italian or Spanish in addition to English, may confer advantages over monolingual English speakers in understanding Shakespeare. We also note that, as a consequence of different education systems, sometimes our additional-language informants had a better understanding of classical cultural references. Interestingly, the Finnish cohort had the lowest level of English of the three groups, had had the least exposure to Shakespeare, and were not specialising in Shakespeare, yet achieved similar results to the other two groups. This result is similar to Zirker et al. (forthcoming: 1), which found that students who had spent at least three months at a school or university in an English-speaking country did not perform better in their comprehension tests of sonnet 43. This would seem to suggest that many difficulties are likely to be common to first and additional-language speakers regardless of language proficiency above a certain level.

Knowing what students find difficult offers the possibility of targeted teaching. However, this knowledge does not in itself constitute a pedagogical approach. We argued that one way of addressing some of the criticisms of textual approaches is to bring corpus-based methods into the classroom. Students are not presented with fixed meanings in a passive way, but are actively engaged in discovering those meanings for themselves. Furthermore, the potential for advanced students to probe the nuances and complexities of meanings is considerable. Corpus approaches do not, or at least do not easily, address all of the linguistic issues we identified as problematic for students. Word-based issues can be tackled, but the complexities of syntax are altogether more difficult. Kettemann and Marko (2004) air arguments from their students against the corpus-based approach to stylistics: (1) destroying the integrity and wholeness of texts and dealing with simple concordance lines; (2) promoting uncritical and superficial reading of texts, promoting an emphasis on surface forms instead of deeper meanings; (3) blurring literary issues (corpus analysis promotes an approach indifferent to the literariness of literary texts). However, just like Kettemann and Marko (2004), we would argue that these concerns are based on the erroneous assumption that corpus analysis is the only analytical instrument or that it could even replace close reading. In fact, more generally, we would argue that a mixed pedagogical approach, combining textual, contextual and performance aspects, is the optimal way forward. 
This is the final pre-publication version of: Murphy, Sean, Culpeper, Jonathan and Gillings, Mathew (2020) What do students find difficult when they read Shakespeare? Problems and solutions. Language and Literature 29(3): 302-326. It may contain minor errors or infelicities.

\section{Acknowledgments}

The research presented in this article was supported by the UK's Arts and Humanities Research Council (AHRC), grant reference AH/N002415/1.

\section{Declaration of conflicting interests}

The authors declared no potential conflicts of interest with respect to the research, authorship, and/or publication of this article.

\section{References}

Ailles JL (2014) 'Is there an app for that?': mobile Shakespeare on the phone and in the cloud. In: Fischlin D (ed) Outerspeares: Shakespeare, Intermedia, and the Limits of Adaptation. Toronto: University of Toronto Press, pp.75-110.

Aston G, Bernardini S and Stewart D (eds) (2004) Corpora and Language Learners. Amsterdam: John Benjamins Publishing.

Berry C (2004) The Working Shakespeare Library. 6 vols. Hal Leonard Corporation. Brayman Hackel HB (2005) Reading Material in Early Modern England: Print, Gender, and Literacy. Cambridge: Cambridge University Press.

Burt SM (2015) 'There's not a lot of negotiation': address terms in an academic department. In: Terkourafi M (ed) Interdisciplinary Perspectives on Im/politeness. Amsterdam: John Benjamins Publishing, pp.71-90.

Clark U and Zyngier S (2003) Towards a pedagogical stylistics. Language and Literature 12(4): 339-351.

Crystal D (2012) Think on My Words: Exploring Shakespeare's Language. Cambridge: Cambridge University Press.

Donaldson A (2016) All the world's: how Shakespeare is viewed around the globe and the role his work can play to support the UK's soft power. Report F305, the British Council.

Elam K (1980) The Semiotics of Theatre and Drama. London: Methuen.

Félix-Brasdefer J and Cohen A (2012) Teaching pragmatics in the foreign language classroom: grammar as a communicative resource. Hispania 95(4): 650-669.

Gibson R (2016) Teaching Shakespeare. Cambridge: Cambridge University Press.

Gilquin $\mathrm{G}$ and Granger S (2010) How can data-driven learning be used in language teaching? In: O'Keeffe A and McCarthy M (eds) The Routledge Handbook of Corpus Linguistics. Routledge: London.

Gorlewski J and Shoemaker B (2013) Research for the classroom: to read or not to read: five approaches to teaching shakespeare. The English Journal 102(4): 111-114.

Hardie A (2012). CQPweb - combining power, flexibility and usability in a corpus analysis tool. International Journal of Corpus Linguistics 17(3): 380-409.

Honegger T (2006) 'Wouldst thou withdraw love's faithful vow?': The negotiation of love in the Orchard Scene (Romeo and Juliet Act II). Journal of Historical Pragmatics 7(1): 73-88.

Johnson K (2014) Shakespeare's English: A Practical Linguistic Guide. Harlow: Pearson.

Kettemann B and Marko G (2004) Can the L in TaLC stand for literature? In: Aston G, Bernardini S and Stewart D (eds) Corpora and Language Learners. Amsterdam: John Benjamins Publishing.

Kizelbach U (2014) The Pragmatics of Early Modern Politics: Power and Kingship in Shakespeare's History Plays. New York / Amsterdam: Rodopi. 
This is the final pre-publication version of: Murphy, Sean, Culpeper, Jonathan and Gillings, Mathew (2020) What do students find difficult when they read Shakespeare? Problems and solutions. Language and Literature 29(3): 302-326. It may contain minor errors or infelicities.

Lanteigne B (2014) Speech event analysis of seventeenth-century military protocol in Hamlet, 1.1: changing of the guard and unknown persons approaching a sentry. Journal of Historical Pragmatics 15(1): 123-147.

Liu, T (2019) Evaluating the Effect of Data-Driven Learning (DDL) on the Acquisition of Academic Collocations By Chinese Learners of English. PhD Thesis, Lancaster University, UK.

Magnusson L (1999) Shakespeare and Social Dialogue: Dramatic Language and Elizabethan Letters. Cambridge: University Press.

McDonald R, Nace ND and Williams TD (2012) Shakespeare Up Close: Reading Early Modern Texts. London: Bloomsbury.

McIntyre D and Walker B (2019) Corpus Stylistics: Theory and Practice. Edinburgh: Edinburgh University Press.

Murphy S (2019) Shakespeare and his contemporaries: designing a genre classification scheme for Early English Books Online 1560-1640, ICAME Journal. 43(1): 5982.

Nyumba TO, Wilson K, Derrick CJ, and Mukherjee N (2018) The use of focus group discussion methodology: insights from two decades of application in conversation. Methods in Ecology and Evolution 9(1): 20-32.

Olive S (2015) Shakespeare Valued: Education Policy and Pedagogy 1989-2009. Bristol: Intellect Books.

Person RF Jr (2009) 'Oh' in Shakespeare: A conversation analytic approach. Journal of Historical Pragmatics 10(1): 84-107.

Rudanko M (1993) Pragmatic Approaches to Shakespeare: Essays on Othello, Coriolanus, and Timon of Athens. Lanham: University Press of America.

Rudanko J (2007) Concepts for analyzing deception in discourse intended to be persuasive: Two case studies from Shakespearean drama. Journal of Historical Pragmatics 8(1): 109-126.

Schupak EB (2018) Shakespeare and performance pedagogy: overcoming the challenges. Changing English 25(2): 163-179.

Shen D (2012) Stylistics in China in the new century. Language and Literature 21(1): 93-105.

Short M (1981) Discourse analysis and the analysis of drama. Applied Linguistics 11(2): 180-202.

Short M (1998) From dramatic text to dramatic performance. In: Culpeper J, Short M and Verdonk P (eds) Exploring the Language of Drama: From Text to Context. London: Routledge, pp.6-18.

Sinclair JM (ed) (2004) How to Use Corpora in Language Teaching. Amsterdam: John Benjamins Publishing.

Vox PoP: Which pedagogy, which play? (2012) Teaching Shakespeare, (1), pp.7.

Wright T (2012) How to be a Brilliant English Teacher. Oxford: Routledge.

Zirker A, Glaesser J, Kelava A, and Bauer, M (2018) Kompetenzmodellierung im Fach Englisch: Literaturwissenschaft meets Psychometrie. In: Bernhart T, Willand M, Richter S and Albrecht A (eds) Quantitative Ansätze in den Literatur- und Geisteswissenschaften. Berlin: De Gruyter, pp.149-172.

Zirker A, et al. (forthcoming) Assessing text comprehension in university students of English as a second language: A new approach. 
This is the final pre-publication version of: Murphy, Sean, Culpeper, Jonathan and Gillings, Mathew (2020) What do students find difficult when they read Shakespeare? Problems and solutions. Language and Literature 29(3): 302-326. It may contain minor errors or infelicities.

\section{Bionotes}

Sean Murphy is a lecturer and researcher. His publications include 'I will proclaim myself what I am: Corpus stylistics and the language of Shakespeare's soliloquies' (2015), and 'Shakespeare and his contemporaries: Designing a genre classification scheme for Early English Books Online 1560-1640' (2019). He was a Senior Researcher on the Encyclopedia of Shakespeare's Language project, and is now a volume editor.

Jonathan Culpeper is Professor of English Language and Linguistics. His publications include Language and Characterisation in Plays and Other Texts (2001) and Early Modern English Dialogues: Spoken Interaction as Writing (2010; with Merja Kytö). He leads the Encyclopedia of Shakespeare's Language project.

Mathew Gillings is an Assistant Professor. His research interests are in all aspects of corpus linguistics, most recently applying the method to the study of deception, Shakespeare's language, and politeness. He is the administrator and communications officer for the Encyclopedia of Shakespeare's Language project.

Michael Pace-Sigge is a senior lecturer. His publications include Lexical Priming in Spoken English (2013). His book, Linked Noun Groups. Opposition and Expansion as Genre and Style Markers, comes out in October 2020.

\footnotetext{
${ }^{1}$ Donaldson A (2016) All the world's: How Shakespeare is viewed around the globe and the role his work can play to support the UK's soft power. Report F305, the British Council.

${ }^{2}$ UK, India, Mexico, Brazil, Turkey, South Africa, Egypt, South Korea, USA, Australia, China, France, Germany, Indonesia, Hong Kong.

${ }^{3}$ Quoted in Ailles (2014).

${ }^{4}$ https://www.thestudentroom.co.uk/

5 The notions of 'first-language' and 'additional-language' speakers are, of course, problematic, especially in the context of multilingualism and global varieties of English.

${ }^{6}$ An additional, intriguing research issue, though again not one this study is designed to address, is whether Shakespeare's contemporaries thought of his works as particularly 'difficult' to read in some sense. We have been unable to find contemporary commentators making such claims. What we do know is that: (a) the early seventeenth-century was experiencing an explosion in printed playbooks with many customers willing to buy them, (b) playbooks were knowingly printed for readers (many containing dedications and letters addressing their readers), (c) wide-ranging abilities in reading were assumed (John Heminge and Henry Condell's address at the beginning of the First Folio of 1623 is entitled "To the great Variety of Readers", a variety defined as "From the most able, to him that can but spell"), and (d) the main concern was not that less able readers would have to work hard to understand something or simply end up perplexed, but that they misinterpret something (especially misinterpretations that may lead to moral corruptness) (evidence supporting all these points can be found in the authoritative work Brayman Hackel 2005, especially pp.72-8).

${ }^{7}$ Cecily Berry was a vocal coach by training, and so it is not surprising that she focusses on the areas of language that she does.

${ }^{8}$ Further references to work involving Shakespeare and pragmatics can be found in the bibliography here: http://wp.lancs.ac.uk/shakespearelang/files/2016/06/Shakespeare-Encyclopaedia-Bibliography.pdf

${ }^{9}$ In total, 92 students participated but only a random sample are included in this study.
} 
This is the final pre-publication version of: Murphy, Sean, Culpeper, Jonathan and Gillings, Mathew (2020) What do students find difficult when they read Shakespeare? Problems and solutions. Language and Literature 29(3): 302-326. It may contain minor errors or infelicities.

${ }^{10}$ The authors would like to thank Alison Findlay of Lancaster University, and Enric Monforte, Clara Escoda and M. Isabel Seguro of the University of Barcelona for kindly allowing us to conduct this study with their students.

${ }^{11}$ Act, scene and line references are to the Arden third editions of the plays. 